\title{
Progranulin Is a Chemoattractant for Microglia and Stimulates Their Endocytic Activity
}

Fiona Pickford, ${ }^{*}$ Jacob Marcus, ${ }^{\dagger}$

Luiz Miguel Camargo, ${ }^{\ddagger}$ Qiurong Xiao, ${ }^{*}$

Danielle Graham, ${ }^{\S}$ Jan-Rung Mo,"

Matthew Burkhardt, ${ }^{\S}$ Vinayak Kulkarni, ${ }^{\neq}$

Jamie Crispino, ${ }^{*}$ Heike Hering, ${ }^{*}$ and

Michael Hutton*

From the Departments of Neuroscience Drug

Discovery, ${ }^{*}$ Bioanalytics and Pathology, Informatics IT, ${ }^{\ddagger}$ CNS

Pharmacology, and Oncology, "T Merck Research Laboratories,

Boston, Massachusetts

Mutations resulting in progranulin haploinsufficiency cause disease in patients with a subset of frontotemporal lobar degeneration; however, the biological functions of progranulin in the brain remain unknown. To address this subject, the present study initially assessed changes in gene expression and cytokine secretion in rat primary cortical neurons treated with progranulin. Molecular pathways enriched in the progranulin gene set included cell adhesion and cell motility pathways and pathways involved in growth and development. Secretion of cytokines and several chemokines linked to chemoattraction but not inflammation were also increased from progranulin-treated primary neurons. Therefore, whether progranulin is involved in recruitment of immune cells in the brain was investigated. Localized lentiviral expression of progranulin in C57BL/6 mice resulted in an increase of Iba1-positive microglia around the injection site. Moreover, progranulin alone was sufficient to promote migration of primary mouse microglia in vitro. Primary microglia and C4B8 cells demonstrated more endocytosis of amyloid 及1-42 when treated with progranulin. These data demonstrate that progranulin acts as a chemoattractant in the brain to recruit or activate microglia and can increase endocytosis of extracellular peptides such as amyloid $\beta$. (Am J Pathol 2011, 178:284-295; DOI: 10.1016/j.ajpath.2010.11.002)

Genetic mutations resulting in haploinsufficiency of the progranulin protein cause a subset of frontotemporal lo- bar degeneration (FTLD-U). ${ }^{1,2}$ FTLD-U is characterized by ubiquitinated cytoplasmic inclusions containing TAR DNA binding protein 43 (TDP-43). ${ }^{3}$ However, little is known about the physiologic or pathogenic role of progranulin in the central nervous system (CNS). Since the initial studies linking progranulin to FTLD-U, progranulin polymorphisms have also been associated with Alzheimer's disease (AD), and haplotypes have been identified that contribute to increased risk of developing $A D \cdot{ }^{4-6}$ Pathologic evidence also links progranulin with AD. Specifically, it has been observed that progranulin was colocalized with $\beta$-amyloid $(A \beta)$ plaques at postmortem examination of brains from patients with $A D^{7}$ and in 3 independent lines of transgenic mice models of $A D .^{8}$ Progranulin is detected at high levels in activated microglia surrounding amyloid plaques, ${ }^{1,8,9}$ consistent with its upregulation in other neuroinflammatory conditions such as Creutzfeldt-Jakob disease, ${ }^{10}$ CNS viral infection, ${ }^{11}$ and amyotrophic lateral sclerosis. ${ }^{12}$ Given the genetic and pathologic evidence linking progranulin to several neurodegenerative diseases, the present study was undertaken in an attempt to understand the physiologic role of progranulin in the brain and to identify mechanisms that may contribute to neurodegeneration.

Progranulin is a $68-\mathrm{kDa}$ secreted protein that is extensively glycosylated to $88 \mathrm{kDa}$. It is composed of a signal sequence and seven and one-half granulin repeats (granulins $A-G$ and paragranulin). Each granulin repeat contains a highly conserved 12 -cysteine motif. ${ }^{13}$ Progranulin is cleaved by elastase and protease 3 , neutrophil-secreted serine proteases, to generate granulins. ${ }^{14,15}$ Secretory leukocyte protease inhibitor binds progranulin and blocks proteolysis by elastase ${ }^{14}$ thus regulating the balance between progranulin and the granulins. Progranulin expression is restricted to mitoti-

Accepted for publication September 23, 2010.

All authors were employed by Merck \& Co. at the time of this research.

Supplemental material for this article can be found at $h$ ttp://ajp.amjpathol.org and at doi:10.1016/j.ajpath.2010.11.002.

Current address of D.G. and H.H.: EMD Serono, Cambridge, MA; of M.H.: Eli Lilly, Erlwood Manor, Windlesham, Surrey, UK.

Address reprint requests to Fiona Pickford, Merck Research Laboratories, 33 Avenue Louis Pasteur, BMB8-114, Boston, MA, 02115. E-mail: fiona_pickford@merck.com. 
cally active epithelial cells, ${ }^{16}$ and hematopoietic cells in the periphery. ${ }^{17}$ In developing brains, progranulin is expressed in sexual dimorphic nuclei. ${ }^{18,19}$ In adult brains, mRNA has been identified in Purkinje cells in the cerebellum, in the granular cell layer of the hippocampus, and in cortical neurons. ${ }^{16}$ Progranulin immunoreactivity has been detected in neurons of the granular cell layer of the hippocampus and in the cortex. Activated microglia are strongly immunoreactive for progranulin. ${ }^{8}$

Interest in progranulin function has been focused on 3 areas: inflammation, tumorigenesis, and more recently, its role in neurodegeneration. Evidence that progranulin has a role in inflammation dates from its discovery, when granulin fragments were first isolated from leukocytes. ${ }^{20}$ Administration of progranulin increased the accumulation of neutrophils, macrophages, blood vessels, and fibroblasts around a cutaneous wound, demonstrating that it is a mediator of the wound response. ${ }^{18}$ The presence of progranulin in myeloid cells and microglia suggested that progranulin may act as an inflammatory modulator. Proinflammatory signals such as tumor necrosis factor (TNF)- $\alpha$ stimulate neutrophils to undergo a "respiratory burst" and release their granule contents (including elastase) and large quantities of reactive oxygen intermediates. Progranulin blocked the TNF- $\alpha$ induced respiratory burst from cultured human neutrophils. In contrast, granulin B induced epithelial cells to release the chemokine interleukin (IL)-8, which attracts neutrophils. ${ }^{14}$ Bone marrow-derived macrophages from progranulin-deficient mice secrete higher levels of proinflammatory cytokines including IL-6 and TNF and less IL-10 than do wildtype cells. ${ }^{21}$ In persons with type 2 diabetes mellitus, serum progranulin levels correlated with macrophage infiltration into omental adipose tissue. Progranulin can also promote chemotaxis of THP-1 monocytic leukemia cells. ${ }^{22}$

Progranulin is up-regulated in a number of tumor cell lines, and is consistently mitogenic. ${ }^{14,18,23-26}$ Progranulin also promotes other oncogenic properties such as invasion and cell survival; SW-13 cells and 5637 bladder cancer cells secrete matrix-degrading enzymes and migrate through Matrigel filters in response to progranulin. ${ }^{27,28}$

Studies of progranulin function in the CNS are limited. Examination of $\mathrm{Grn}^{-1-}$ mice revealed a role for progranulin in modulating the brain serotonergic system to establish sexual dimorphic behaviors. ${ }^{29}$ Progranulin can mediate TDP-43 cleavage in vitro. ${ }^{30}$ Consistent with its role in promoting cell survival and mitogenesis in the periphery, progranulin promotes neuronal survival ex vivo. ${ }^{31}$ A second line of $\mathrm{Grn}^{-1-}$ mice exhibit exaggerated inflammation, demonstrate impaired ability to clear bacterial infections, and develop cytosolic TDP-43 neuronal inclusions. ${ }^{21}$

In the present study, microarrays and cytokine arrays were used to identify neuronal pathways modulated by progranulin. From these data, it was hypothesized that similar to its role in the periphery, progranulin may also be involved in modulating the response to injury in the CNS. Consistent with this proposed function, it was further demonstrated that progranulin can act as a chemoattrac- tant for microglia and is able to promote their capacity to phagocytose extracellular peptides including $A \beta$.

\section{Materials and Methods}

\section{Human Progranulin Production and Purification}

Human progranulin ${ }^{13}$ in pcDNA3.1V5HisTOPO (Invitrogen Corp, Carlsbad, CA) was transiently expressed in HEK293 cells to ensure appropriate glycosylation. Conditioned medium from the progranulin-transfected cells was loaded onto a nickel resin affinity column (Qiagen Inc, Valencia, CA) and eluted in $0.3 \mathrm{mmol} / \mathrm{L}$ of imidazole in $20 \mathrm{mmol} / \mathrm{L}$ of Tris, $\mathrm{pH} 8$, and $150 \mathrm{mmol} / \mathrm{L}$ of sodium. The eluate was dialyzed against $10 \mathrm{mmol} / \mathrm{L}$ of sodium phosphate, $\mathrm{pH} 7.4,100 \mathrm{mmol} / \mathrm{L}$ of sodium, and $10 \%$ glycerol. Protein concentration was calculated based on the Bradford method using a kit (Smart Plus; Bio-Rad Laboratories, Inc, Hercules, CA).

\section{SW13 Cell Proliferation Assay}

SW13 (adrenal cortical adenocarcinoma) cells were obtained from American Type Culture Collection (Manassas, VA) and maintained in Dulbecco modified Eagle medium (DMEM)/F12 (Invitrogen Corp) supplemented with $10 \%(\mathrm{v} / \mathrm{v})$ heat-inactivated FBS (Sigma-Aldrich, St. Louis, MO) and $10 \mathrm{mmol} / \mathrm{L}$ of HEPES (Invitrogen Corp). Cells (5000/well) were plated in a 96-well plate and allowed to adhere overnight. The following day, the cells were starved by serum deprivation for 4 hours, then treated with varying concentrations $(0,37,111,333$, or $1000 \mathrm{nmol} / \mathrm{L}$ ) of progranulin diluted in media without serum. Positive control wells contained serum. Cells were incubated for 72 hours; then a cell-proliferation assay was performed using a luminescence-based kit (ViaLight Plus; Lonza Bioscience, Basel, Switzerland) following the manufacturer's protocol. Luminescence output was measured using a plate reader (EnVision; PerkinElmer Inc, Waltham, MA).

\section{Neuron Culture}

Cortices were dissected from embryonic (day 18) Sprague-Dawley rats, collected in cold HBSS, dissociated using papain (LK003178; Worthington Biochemical Corp, Lakewood, NJ), triturated, strained, and plated at $6 \times 10^{5}$ in 6-well plates coated with poly-d-lysine. Cells were initially plated for 3 hours in Neurobasal medium (Invitrogen Corp) with $10 \%$ FBS, then maintained for 14 days in Neurobasal medium with 1\% B27, glutamine, and glucose. Neurons were treated for 8 hours with either medium containing $10 \mathrm{nmol} / \mathrm{L}$ of human progranulin or medium with the same volume of PBS solution.

\section{Microarray Analysis and Identification of PGRN Gene Signature}

Gene expression analysis was conducted using custom arrays (Rat GeneChip; Affymetrix, Inc, Santa Clara, CA) 
containing approximately 33703 genes, 43686 probe sets. Isolated total RNA samples were assayed for quality using a bioanalyzer (Agilent Technologies, Inc, Santa Clara, CA) and yield (Ribogreen; Molecular Probes, Inc/ Invitrogen Corp, Eugene, OR) metrics before amplification. Samples were amplified and labeled using a custom automated version of the Ovation amplification protocol (NuGen Technologies, Inc, San Carlos, CA). Hybridization, labeling, and scanning using ovens, fluidics stations, and scanners (all from Affymetrix, Inc) following the protocols recommended (NuGen Technologies, Inc). Sample amplification, labeling, and microarray processing were performed by Rosetta Inpharmatics Gene Expression Laboratory (Seattle, WA). Data were loaded into the Resolver system (version 6.0; Rosetta Biosoftware, Kirkland, WA). Experiment intensity profiles were built using Robust Multichip Averaging via power tools (Affymetrix, Inc) from scans using only the perfect-match probes. MAS5 $P$ values were calculated using perfectmatch and mismatch probes to determine whether expression was present or absent for a given probe (22704 probes had a MAS5 $P$ value $<0.05$ ). A principal component analysis was performed to determine whether distinct expression from the various treatments, progranulin and PBS, could be observed. The Resolver system creates ratio experiments from intensity experiments using an error-weighted average, as described. ${ }^{32}$ Ratios for each gene in each individual replicate were created to a control (PBS, $n=5$ ) pool, respectively. $P$ values were generated and assigned to each ratio, and represent the probability that a given gene is significantly expressed. ${ }^{32}$ To determine a reliable probe set for treatment comparisons, only those probes with MAS5 $P$ value $<0.05$, a ratio $P$ value $<0.01$, and absolute change 1.2-fold or greater in at least $20 \%$ of the samples were considered. After filtering, 903 probes were used, for an error-weighted 1 analysis of variance comparing PBS-treated $(n=5)$ versus progranulin-treated $(n=5)$ samples, yielding a signature of 168 with analysis of variance $P<0.01$.

Gene ontology and pathway enrichment analysis was performed using a hypergeometric test. In brief, a hypergeometric test was performed to determine whether a particular category (e.g., biological process or pathway) was disproportionately represented in a given set of genes (e.g., those that were differentially expressed in a particular group) compared with a reference set (all of the genes in the GeneChip array). Rat genes were first converted to corresponding human orthologs using the nucleotide-nucleotide Basic Local Alignment Search Tool (BLASTN; US National Center for Biotechnology Information, US National Library of Medicine, Bethesda, MD) ( $E$ value $<0.5$ cut off) ${ }^{33}$ before enrichment analysis. Pathway and biological processes sets were obtained using KEGG (Kyoto Encyclopedia of Genes and Genomes), ${ }^{34}$ Gene Ontology Project (Biological Process and Cellular Component), ${ }^{35}$ Metacore (GeneGo, Inc, St. Joseph, MI), and PANTHER (Protein Analysis THrough Evolutionary Relationships) ${ }^{36}$ databases, and IPA software (Ingenuity Systems Inc, Redwood City, CA).

\section{Construction of the FTD, FTLD-U, and PGRN Signature Network}

To determine whether genes from 3 different studies interacted with each other (binding or by regulation), protein interaction and regulation information from several public and commercial sources was used. Genes with only one interaction were considered. The constructed network contains 156 nodes (genes) and 227 edges (regulatory or binding interactions).

\section{Cytokine Profiling}

Conditioned media were collected from the same primary neurons treated with $10 \mathrm{nmol} / \mathrm{L}$ of progranulin. Samples were biotinylated and dialyzed before being added to glass slide-based antibody arrays, and were incubated at room temperature. The RayBio Biotin Label-based Rat Antibody Array (RayBiotech, Inc, Norcross, GA) contained antibody spots for 90 rat cytokines. After incubation with fluorescent dye-streptavidin, the signals were visualized via fluorescence. Antigen level intensity data were adjusted for background, and normalized according to protocols of the manufacturer (RayBiotech, Inc). Ratio data for each individual antigen were created as follows: PBS baseline samples were created by pooling all replicates $(n=4)$. The log10 ratio of each individual replicate, for each treatment group (PBS or PGRN), to PBS pool was derived. Antigen expression differences were determined using the $t$ test on log10 ratio data by comparing PGRN with PBS replicates.

\section{Lentivirus Production}

Human progranulin $\mathrm{CDNA}^{13}$ was amplified from PGRN/ pcDNA3.1 using the following primers: 5'-CACCATGTGGACCCTGGTGAGC-3', 5'-CAGCAGCTGTCTCAAGGCTG-3', and 5'-CTACAGCAGCTGTCTCAAGGCTG-3'. Human PGRN was subcloned into pENTR with the pENTR/D-TOPO Cloning Kit (Invitrogen Corp) and subsequently into pLenti7.3 using the Gateway system (Invitrogen Corp). Packaging cell line HEK293FT was infected with various viral constructs to produce the viruses. Green fluorescent protein (GFP)-lenti (pLenti6.3/ V5-GW/EmGFP Expression Control Vector) was obtained from Invitrogen Corp.

\section{Lentivirus Injection}

Anesthetized mice were restrained in a stereotaxic frame and injected using a Lab Animal Studies Injector (LASI) needle attached to a 1700 Series Gastight Syringe (both from Hamilton Co, Reno, NV) in a Harvard PHD 22/2000 Advance Syringe Pump (Harvard Apparatus, Inc). GFPlentivirus was injected into the cortex of one hemisphere, and progranulin-lentivirus in the contralateral hemisphere following the coordinates AP, $1.0 \mathrm{~mm}$; ml, [plus or minus] $1.8 \mathrm{~mm}$; and DV, $-0.8 \mathrm{~mm}$. The virus was administered at an infusion rate of $0.2 \mu \mathrm{L} / \mathrm{min}$ for 10 minutes. After viral administration, the needle was allowed to rest for 5 minutes, and was slowly retracted. This process was 
repeated for the second infusion site. The animals were allowed to recover on a heating pad, and were returned to a cage after they were fully cognizant. Mice were euthanized and tissue harvested at 2, 7, or 14 days after injection.

\section{PBS Lesion}

Anesthetized 2-month-old $\mathrm{Grn}^{-1-}$ mice and wild-type littermates ${ }^{29}$ were restrained in a stereotaxic frame as described for lentivirus injection. Two microliters of sterile PBS was injected into the cortex (coordinates as above) with a 26-gauge needle mounted on a syringe (Hamilton Co) at a rate of $0.5 \mu \mathrm{L} / \mathrm{min}$. Mice were euthanized and tissue harvested at 7 days after creation of lesions.

\section{Immunohistochemistry and Image Processing}

Mice were euthanized using carbon dioxide according to guidelines of the Institutional Animal Care and Use Committee (Michigan State University, East Lansing), then perfused transcardially with PBS $(\mathrm{pH} \mathrm{7.4)}$ for 1 minute and immersion fixed in 10\% neutral buffered formalin for 24 hours. Forebrains were either cyroprotected in 20\% sucrose overnight and sectioned at $30 \mu \mathrm{m}$ into 6 adjacent series on a freezing microtome or processed into paraffin molds using standard procedures and sectioned serially at $5 \mu \mathrm{m}$. Paraffin sections were immunostained using an automated stainer (Discovery XT; Ventana Medical Systems, Inc, Tucson, AZ) with polyclonal rabbit anti-ionized calcium binding adaptor molecule-1 (Iba-1; diluted 1:1000; Wako Pure Chemical Industries, Ltd, Osaka, Japan; catalog No. 019-19741) and polyclonal goat antiprogranulin (1:1000; R\&D Systems, Inc, Minneapolis, MN; catalog No. AF2420). Floating sections were stained by hand using anti-lba-1 diluted 1:2000 using standard procedures. In brief, sections were incubated with $3 \%$ hydrogen peroxide, blocked in donkey serum, and exposed to primary antibody overnight at room temperature. Sections were incubated with biotinylated donkey anti-goat secondary antibody, amplified with avidin-biotin complex (Vector Laboratories, Inc, Burlingame, CA), and visualized with 3-3'-diaminobenzidine as the chromagen. Sections were mounted, dehydrated, and coverslipped. Immunostaining was quantified using a slide scanning and analysis system (Ariol; Applied Imaging Corp, San Jose, CA).

Injection sites were located via PGRN immunoreactivity in the cortex, and adjacent slides were stained for Iba-1. The amount of PGRN immunoreactivity on the injected (PGRN-lenti) and control (GFP-lenti) hemispheres was quantified by measuring the number of pixels above a color intensity threshold around the injection sites. Within these regions on adjacent slides, the number of Iba-1 immunoreactive microglia were counted using color and shape thresholds. For floating sections, injection sites were identified via needle-tracks, and Iba-1 immunoreactive microglia were quantified in the region surrounding the injections. For each injection, 3 to 5 sections were stained and quantified.
Fluorescent immunostaining was performed on paraffin sections as described, with modifications as follows. After antigen retrieval, slides were exposed to primary antibodies to anti-neuronal nuclei (NeuN; 1:1000; Millipore Corp, Billerica, MA; catalog No. MAB377), Iba-1 (1:1000), or glial fibrillary acidic protein (1:1000; DAKO Corp, Carpenteria, CA; catalog No. Z0334) in conjunction with anti-progranulin (1:100). ALEXA-488 or ALEXA-594 (Molecular Probes, Inc/Invitrogen Corp) conjugated donkey anti-mouse (NeuN), rabbit (glial fibrillary acidic protein, Iba-1), and goat (PGRN) secondary antibodies were then applied. Slides were coverslipped using a kit (ProLong Anti-Fade; Molecular Probes, Inc/Invitrogen Corp) with DAPI (4',6-diamidino-2-phenylindole) fluorescent stain, and imaged.

\section{Microglia Culture}

Cerebral hemispheres were dissected from P1 C57BL/6 mice in HBSS. Tissue was triturated in HBSS and strained through a $100-\mu \mathrm{mol} / \mathrm{L}$ cell strainer. Cells were spun down, resuspended in high modified DMEM with glutamine (GlutaMAX; Invitrogen Corp) with 10\% heat-inactivated FBS, and plated in $20 \mathrm{ml}$ of media and $25 \mathrm{ng} / \mathrm{ml}$ of recombinant mouse granulocyte macrophage colonystimulating factor (rmGM-CSF) (R\&D Systems, Inc, Minneapolis, MN) at 2 brains per P75 flask. Ten milliliters of media was replaced every 5 days. On day 14, microglia lightly adhering to the surface of the mixed culture were shaken off and harvested for subsequent experiments.

\section{Microglial Migration Assay}

Primary mouse microglia were starved via serum deprivation overnight in DMEM, and plated at $1 \times 10^{5}$ cells/ well in $200 \mu \mathrm{L}$ of medium in the upper chamber of Transwell permeable supports (8.0- $\mu \mathrm{m}$ pore size, polycarbonate membrane, $6.5-\mathrm{mm}$ diameter, 24-well format) (Corning Inc, Corning, NY). Four hundred microliters of media containing chemoattractants (FBS and progranulin) was added to the lower chamber, and cells were incubated for 24 hours. Cells that migrated to the lower chamber were stained with CyQUANT NF green fluorescent dye (Invitrogen Corp) using the manufacturer's protocol. Cells were removed from the upper chamber using a cotton swab, and migrated cells were counted using a fluorescent microscope. Cells were counted in 5 fields (10x magnification) per well. Data are given as the mean of 3 experimental replicates.

\section{Endocytosis Assay}

$5 \times 10^{5}$ primary mouse microglia were incubated in DMEM with $10 \%$ heat-inactivated FBS overnight. Cells were incubated with recombinant human progranulin, human A $\beta 1-42$ conjugated with HiLyte Fluor 488 (Anaspec, Inc, San Jose, CA), cytochalasin D (Sigma-Aldrich), insulin (Invitrogen Corp), or bone-derived neurotrophic factor (Sigma-Aldrich) for 2 hours. Cells were washed thoroughly in PBS and harvested. Measurements were performed using a cytometer (FACSCalibur; BD Bio- 
sciences, San Jose, CA). The cell population was selected by a forward and side scatter window. The FL1 channel fluorescence (fluorescein isothiocyanate) was recorded, and 10000 events were acquired. Data were analyzed using commercially available software (FlowJo; Tree Star Inc, Ashland, OR) using a histogram to gate the fluorescein isothiocyanate-positive cell population. Microglia adhered to coverslips coated with poly-d-lysine were placed in the same wells. Cells were incubated for 30 minutes with LysoTracker Red (Invitrogen Corp), fixed with $4 \%$ paraformaldehyde, and mounted using Prolong Gold antifade reagent containing DAPI (Invitrogen Corp). Fluorescence images were acquired using a confocal microscope system (LSM510META; Carl Zeiss AG, Oberkochen, Germany) and a microscope (Axioplan; Carl Zeiss AG) using a 40× water immersion lens.

\section{Results}

\section{Generation of Biologically Active Human Progranulin}

Human progranulin was expressed and purified from human embryonic kidney cells to ensure appropriate glycosylation. To confirm that it was biologically active, SW13 cells, known to proliferate in response to progranulin, ${ }^{23}$ were starved via serum deprivation, and incubated with increasing concentrations of progranulin. Cell proliferation was dose-dependent in response to progranulin (see Supplemental Figure S1, http://ajp.amjpathol.org). The increase in cell number was statistically significant at $111 \mathrm{nmol} / \mathrm{L}$, to $157 \%$ of control ( $P=0.03, t$ test). Evidence from the literature suggested that neurons may respond to progranulin at lower concentrations ${ }^{31}$; therefore, we chose 10 to $100 \mathrm{nmol} / \mathrm{L}$ for subsequent experiments.

\section{Gene Expression Signature of Progranulin-Treated Neurons}

Primary neurons (14 days in vitro) from embryonic (day 18) Sprague-Dawley rats were treated with $10 \mathrm{nmol} / \mathrm{L}$ of human progranulin for 8 hours. Human progranulin is $75 \%$ identical and $84 \%$ similar to rat progranulin. Cells were harvested, and RNA was isolated and analyzed using a microarray to determine changes in gene signatures between progranulin and control samples. The progranulin gene expression signature consisted of 168 probes differentially expressed, compared with controls (see Supplemental Table S1, http://ajp.amjpathol.org). A clear separation of the treatment groups was observed along the first principal component of a principle component analysis (see Supplemental Figure S2, http://ajp. amjpathol.org). Data were analyzed to identify pathways enriched for genes affected by progranulin. From this analysis, the inherent bias in the gene expression signature was identified, which may shed light on biological processes or pathways that are regulated by progranulin. Biological processes and pathways enriched (hypergeo-

Table 1. Pathways Enriched for Progranulin-Treated Primary Neuron Gene Set

\begin{tabular}{lll}
\hline \multicolumn{1}{c}{ Similar Set } & Collection \\
\hline Neurophysiologic process dopamine D2 receptor signaling in CNS & GeneGo Pathways \\
Biological adhesion & GO Biological Process \\
Cell adhesion & GO Biological Process \\
Regulation of developmental process & GO Biological Process \\
Regulation of biological quality & GO Biological Process \\
Positive regulation of keratinocyte differentiation & GO Biological Process \\
Neurophysiologic process $\Delta$-type opioid receptor in nervous & GeneGo Pathways & 0.000945 \\
system & GO Biological Process \\
Regulation of cellular component organization & GO Biological Process \\
Developmental process & GO Biological Process \\
Regulation of cellular component size & GO Biological Process \\
Regulation of actin filament length & GO Biological Process \\
Actin polymerization or depolymerization & GO Biological Process \\
Regulation of actin polymerization or depolymerization & GO Biological Process \\
Regulation of organelle organization & GO Biological Process \\
Regulation of cell proliferation & GO Biological Process \\
Keratinocyte differentiation & GO Biological Process \\
Regulation of keratinocyte differentiation & GeneGo Pathway \\
Development EPO-induced MAPK pathway & GO Biological Process \\
Regulation of locomotion & GO Biological Process \\
Regulation of cell motion & GO Biological Process \\
Regulation of cytoskeleton organization & GO Biological Process \\
Regulation of cell migration & GO Biological Process \\
Positive regulation of cell motion & GO Biological Process \\
Regulation of actin filament-based process & GO Biological Process \\
Regulation of actin cytoskeleton organization & GO Biological Process \\
Positive regulation of cell migration & GO Biological Process \\
Cell motility & 0.000710 \\
\hline
\end{tabular}

Rat primary cortical neurons were treated with $10 \mathrm{nmol} / \mathrm{L}$ of progranulin for 8 hours, and changes in gene expression were measured using a microarray. Gene ontology and pathway enrichment analysis was performed. Pathways listed were disproportionately represented with the progranulin gene set $(P<$ 0.001). Pathway sets were obtained from KEGG, Gene Ontology, GeneGo, PANTHER, and Ingenuity pathways.

EPO, erythropoietin; MAPK, mitogen-activated protein kinase. 
A

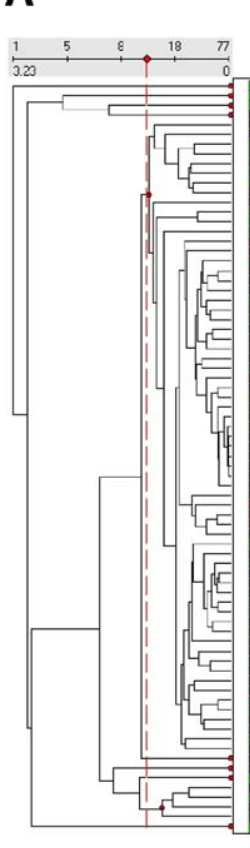

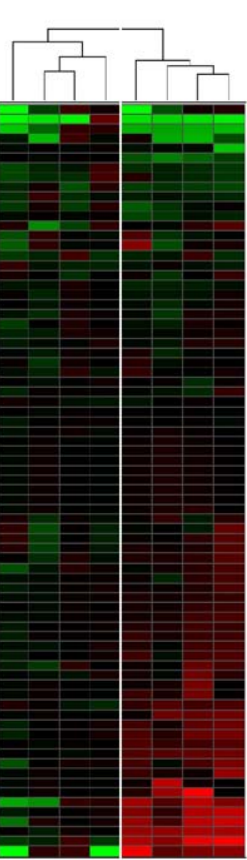

PBS PGRN
B

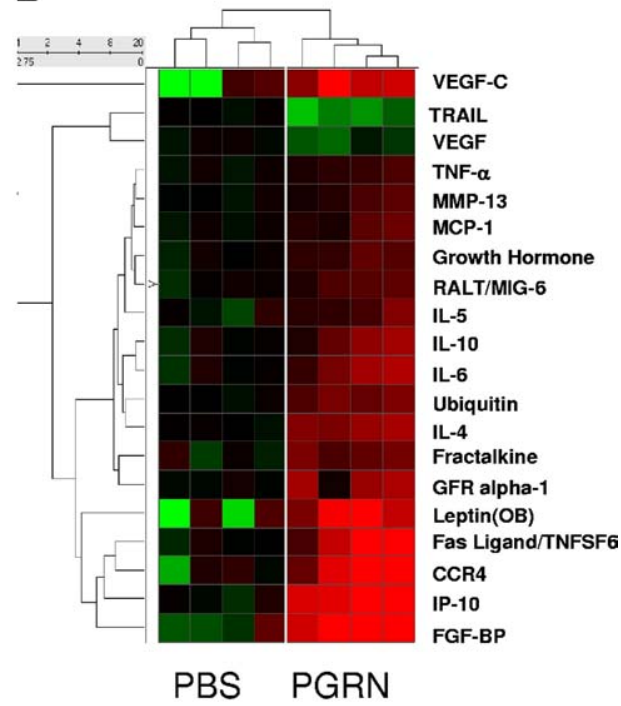

Figure 1. Changes in cytokines secreted from progranulin-treated primary neurons. Levels of 90 cytokines in conditioned media from rat primary cortical neurons treated with $10 \mathrm{nmol} / \mathrm{L}$ of progranulin for 8 hours. Cytokines were measured using a biotin label-based rat antibody array. A: Heat map shows cytokine levels normalized to a control pool. B: Cytokines from progranulin-treated media that were significantly different from controls. Red; upregulated, green; downregulated. metric $P<0.001$ ) in the progranulin signature included pathways associated with cell migration or motility, cytoskeleton organization, cell adhesion, and cell proliferation (Table 1).

To determine whether the progranulin gene expression signature described herein was relevant to disease, results of the present study were compared with 2 published gene expression signatures from brains with FTLD. ${ }^{37,38}$ Only 1 gene, PARP3, was down-regulated in both the progranulin signature and the FTLD signature described by Bronner et al. ${ }^{37}$ The lack of overlap is expected because these gene expression signatures were derived in different biological conditions. For example, both FTLD and FTLD-U studies were performed using postmortem brain tissue containing multiple cell types, with different patient populations, and at a late stage of disease. Conversely, the progranulin signature described herein was derived in a rat neuron cell culture system and measured after 8 hours. A more relevant analysis would be to determine whether common processes or pathways are affected in all of these models; thus, we wondered whether any of the genes regulate or interact with each other based on regulatory interactions described in the literature. A subset of genes from all 3 studies form an interconnected network, indicating that the 3 results may converge on certain common biological processes (see Supplemental Figures S3 and S4, http:// ajp.amjpathol.org). Furthermore, identification of pathways enriched for genes in the combined gene subset revealed several similar pathways to the progranulintreated neurons including positive regulation of cellular component movement, positive regulation of locomotion, positive regulation of cell migration, transport macropinocytosis regulation by growth factors, regulation of cell adhesion, and regulation of cell proliferation $(P<0.004)$.
This indicates that certain processes identified as being modified by transient progranulin treatment were consistent with those identified as differentially regulated in brain samples from patients with FTLD.

\section{Cytokines Secreted from Primary Neurons Treated with Progranulin}

To identify whether progranulin also has a role in mediating the inflammatory response in the CNS, conditioned media from the same primary neurons were analyzed using an antibody-based array to identify changes in secreted cytokines. Data were analyzed as described (Materials and Methods section), using similar principles to the gene expression arrays. Biological replicates were consistent between the progranulin-treated and control groups, demonstrating the consistency of the method (Figure 1A). Of 90 cytokines measured, 18 were significantly up-regulated and 2 were significantly down-regulated. There was a striking overlap between the gene pathways altered by progranulin treatment and the cytokines secreted by the same neurons. For example, pathways associated with cell migration, cytoskeletal organization, cell motility, and cell adhesion were significantly enriched in the progranulin-treated gene set. These correlated with increased expression of numerous cytokines and chemokines involved with chemotaxis and cell motility such as interferon-inducible protein-10, monocyte chemoattractant protein-1, matrix metalloprotease-13, fractalkine, C-C chemokine receptor type 4, and glial cell-derived neurotrophic factor receptor $\alpha-1$. Cell proliferation pathways were enriched in the gene set that may be associated with secretion of growth and death factors such as TNF-related apoptosis-inducing ligand 


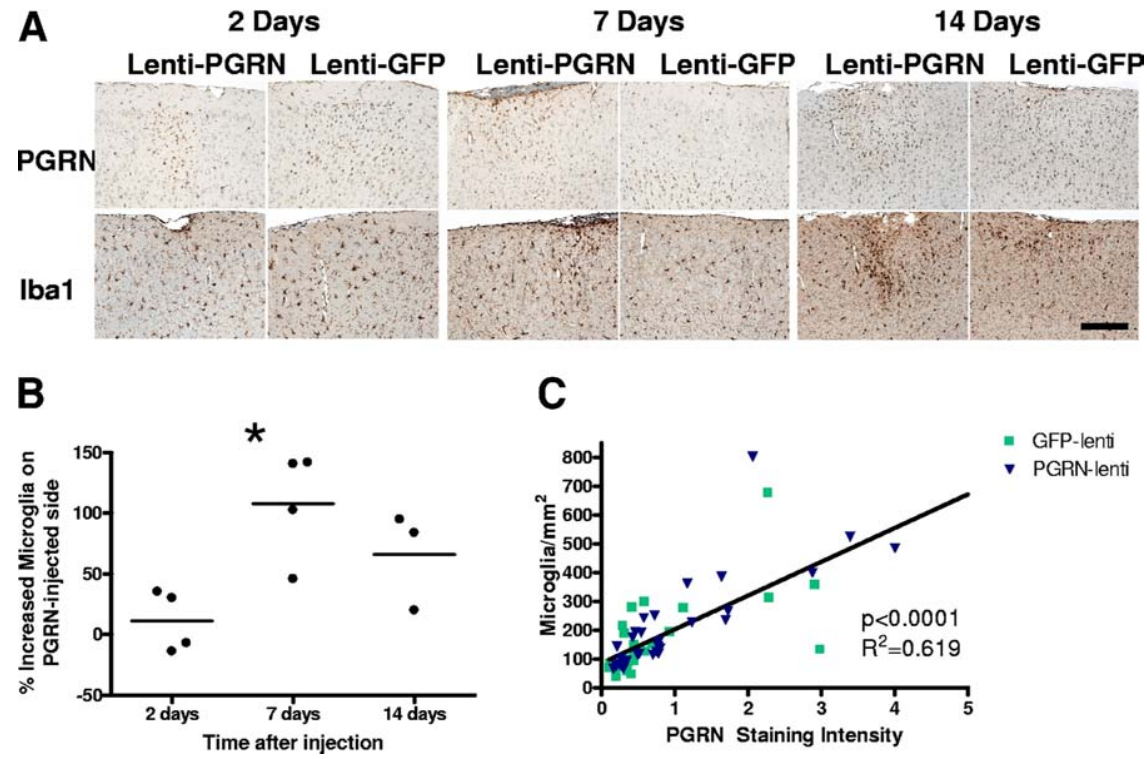

Figure 2. Progranulin attracts microglia in the brain. A: Representative C57BL/ 6 cortical brain sections containing the PGRN (progranulin)lenti or GFP-lenti injection site immunostained for progranulin or the microglial marker Iba1. Mice were sacrificed at 2, 7, or 14 days after injection. Scale bar $=200 \mu \mathrm{m}$. B: Quantification of the number of microglia surrounding the PGRN-lenti injection site normalized to the number of microglia surrounding the GFP-lenti injection site, expressed as a percentage increase. Each point represents the mean value from 3 to 4 sections analyzed per mouse (analysis of variance, $P=0.02$; Dunnet post hoc test ${ }^{*} P<0.05$. C: Number of microglia recruited to the injection site correlated closely with progranulin staining intensity. Each data point was obtained from 1 brain section (green square, GFP-lenti injection; blue triangle, PGRN-lenti expression).
(TRAIL), vascular endothelial growth factor-C, and Fas ligand. Secretion of cytokines IL-10, IL-6, IL-4, and IL-5 was significantly increased. TNF- $\alpha$ was slightly elevated (1.6-fold; $P<0.05$ ), whereas interferon- $\gamma$, IL-2, IL-1 $\beta$, and associated receptors were not elevated. Therefore, Th2 cytokines were strongly induced, but classic proinflammatory factors were not induced by progranulin treatment.

These data suggested that progranulin may be involved in chemotaxis, cell growth, and survival and in modulating the inflammatory response in the brain. Because of the established role of progranulin in wound healing and attraction of leukocytes to sites of injury in the periphery, ${ }^{14}$ and the recent discovery that serum progranulin concentrations correlated with macrophage infiltration in adipose tissue, ${ }^{22}$ it was hypothesized that progranulin may promote chemotaxis of immune cells in the brain, and attempts were made to confirm this via in vivo and in vitro experiments.

\section{Progranulin Locally Increases Iba1-Positive Microglia in Brain}

Lentivirus expressing either human progranulin or GFP was injected into the cortex of C57BL/6 mice. After 2, 7, or 14 days ( $n=3$ to 4 per group), brains were harvested and processed for single or double immunohistochemistry with GFP, progranulin, Iba-1, glial fibrillary acidic protein, and NeuN antibodies on 5- $\mu \mathrm{m}$ paraffin sections (Figure 2). The specificity of the progranulin antibody was confirmed by the absence of staining in $\mathrm{Grn}^{-1-}$ mouse brain sections and by the absence of staining by an isotype control antibody (see Supplemental Figure S5, http://ajp.amjpathol.org). Iba-1 is a $\mathrm{Ca}^{++}$binding protein specifically produced by activated monocytes and microglia. Progranulin was present in the parenchyma surrounding the progranulin-lentivirus injection site, and was strongly expressed in adjacent neurons and microglia (see Supplemental Figure S6, http://ajp.amjpathol.org).
Endogenous progranulin was weakly expressed in neurons and strongly expressed in microglia surrounding the GFP-lentivirus injection site. Progranulin did not co-localize with glial fibrillary acidic protein immunoreactivity.

Progranulin immunoreactivity intensity and numbers of Iba1-positive microglia were quantified around each injection site. The number of activated microglia around the progranulin injected site were normalized to the number of microglia around the GFP injection site to calculate the percent increase in number of microglia and to control for increased microglial activation from the injection alone. Progranulin expression started to increase after 2 days, was clearly present around the progranulin-lentivirus injection site after 7 days, and continued through 14 days (Figure 2A). There was also an increase in progranulin expression in microglia around the GFP-lentivirus injection site, suggesting that the trauma of the injection process was sufficient to induce endogenous mouse progranulin expression in this cell type. This could be detected in the same sections because the antibody detected both mouse and human progranulin. The number of activated microglia surrounding the injection site was higher around the progranulin injection site than around the GFP injection site (Figure 2A), and the percent increase of microglia on the progranulin-lentivirus injected side compared with the GFP-lentivirus injected side was increased between days 2 and 7 after injection (Figure 2B), (analysis of variance, $P=0.02$ ). Furthermore, progranulin expression tightly correlated with the number of microglia in the region $\left(R^{2}=.619 ; P<0.001\right.$, Pearson correlation) (Figure 2C). Highly significant correlations were observed in both the region expressing human progranulin from the lentiviral injection $\left(R^{2}=0.69\right.$, $P<0.001$, Pearson correlation) and the region surrounding the GFP-lentiviral injection when endogenous mouse progranulin was induced after the trauma of the injection ( $R^{2}=0.42 ; P<0.001$, Pearson correlation). To our knowledge, these data demonstrate for the first time that 


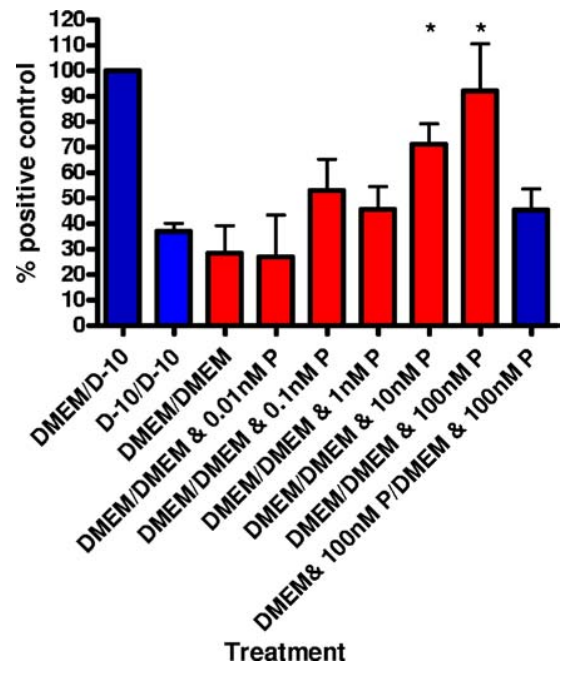

Figure 3. Progranulin promotes microglial migration in vitro. Histogram of number of primary mouse microglia that migrated across a Transwell membrane toward the chemoattractants progranulin (P) or 10\% FBS in DMEM (D-10). Results are the mean of 3 separate experiments, expressed as a percentage of the positive control $(10 \% \mathrm{FBS}) .{ }^{*} P<0.05$ compared with DMEM/DMEM (no chemoattractant gradient) calculated using the $t$ test.

increased levels of progranulin, both human and mouse, increase the number of activated microglia in the brain.

\section{Progranulin Promotes Microglial Migration in Vitro}

The increase in Iba1-positive microglia described may be due to the effect of progranulin on activating resident microglia or by recruiting distal microglia via chemotaxis. Therefore, to determine whether progranulin acts as a chemoattractant, an in vitro migration assay was performed. Microglia cultured from P1 C57BL/6 mice were plated in the upper chamber of Transwell plates and on the upper surface of the Transwell membrane, whereas progranulin or other chemoattractants were added to medium in the lower well. A diffusion gradient formed across the Transwell membrane. The cells were incubated for 24 hours and stained with Cyquant NF, and the number of cells on the lower side of the membrane was counted. Positive controls were $100 \mu \mathrm{mol} / \mathrm{L}$ of ATP (data not shown) and 10\% FBS (Figure 3), and both induced migration of cells across the membrane toward the higher concentrations. Ten nanomoles per liter of progranulin was sufficient to promote migration of the microglia across the Transwell membrane, and the number of cells that migrated across the membrane increased with progranulin treatment in a dose-dependent manner (Figure 3). To test whether increased migration across the membrane was observed, or increased adherence of cells to the membrane, cells were treated with $100 \mathrm{nmol} / \mathrm{L}$ of progranulin in both the upper and lower chambers. With high progranulin levels but no gradient across the membrane, the number of microglia on the lower side of the membrane did not increase, demonstrating that progranulin did not affect adherence in this experiment. These data show that progranulin is sufficient to act as a chemoattractant to microglia.

\section{No Difference in Iba1-Positive Microglia in PBS-Lesioned Progranulin-Deficient Mice}

Although progranulin can increase activated microglia in vivo (Figure 2) and can act as a chemoattractant in vitro (Figure 3), it is not clear whether it is absolutely required for these processes. In progranulin-deficient mice $\left(\mathrm{Grn}^{-1-}\right)$ and wild-type littermates, lesions were created by injecting $1 \mu \mathrm{L}$ of sterile PBS with a wide-gauge needle into the cortex, and the number of Iba1-positive microglia surrounding the injection site was counted. Brains were processed as described for free-floating immunohistochemistry, and were analyzed as before. The number of microglia surrounding the injection site was normalized to the number of microglia in a corresponding region of the contralateral cortex without lesions to control for interindividual variation. There was no significant difference in the number of microglia recruited to the site of the PBS lesion in the $\mathrm{Grn}^{-1-}$ mice compared with the wild-type littermates (Figure 4). These data demonstrate that, at least for this lesion, factors other than progranulin can also act as chemoattractants for microglia.

\section{Microglial Endocytosis Is Increased in Response to Progranulin}

From observations that pathways involved in cytoskeletal organization and actin polymerization were enriched in the gene signature of progranulin-treated neurons (Table 1 ), it was hypothesized that progranulin may also regulate endocytosis. Progranulin co-localizes with $A \beta$ in amyloid plaques in brains of patients with $A D$ and in mouse
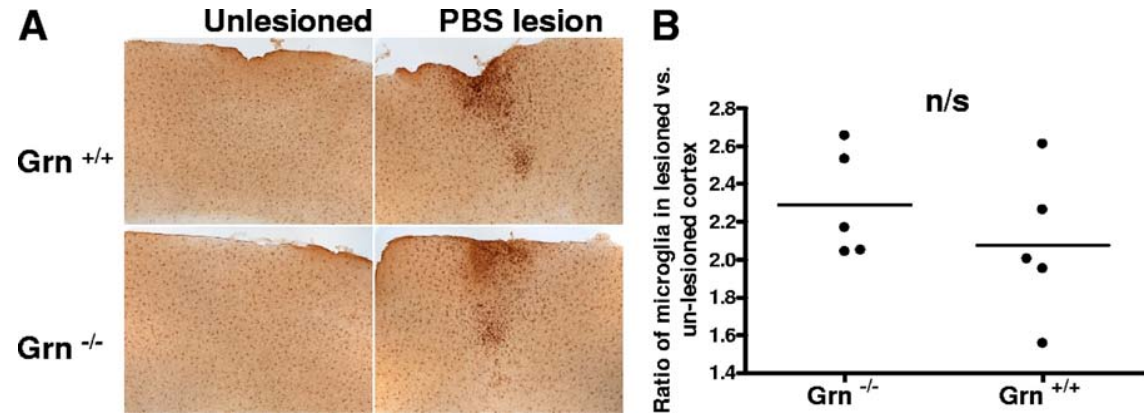

Figure 4. No difference is observed in microglial migration in progranulin-deficient mice with lesions created using PBS. A: Number of Iba1-positive microglia surrounding a PBS lesion in progranulin knockout $\left(\mathrm{Grn}^{-/-}\right)$and wild-type $\left(\mathrm{Grn}^{+/+}\right)$mice. B: Each point represents the mean of 3 to 5 sections analyzed per mouse. There was no significant difference between the groups ( $t$ test) 
models of AD (see Supplemental Figure S7, http://ajp. amjpathol.org), ${ }^{8,39}$ and can be endocytosed by microglia. Therefore, fluorescently tagged $A \beta$ was used as a substrate to test whether progranulin could increase endocytosis in an in vitro system. C8B4 cells (a mouse microglial cell line) were incubated with freshly solubilized A $\beta 1-42$ tagged with Hilyte-488 for 2 hours in the presence or absence of progranulin. Cells were trypsinized, washed thoroughly to remove any extracellular $A \beta$, harvested, and analyzed using flow cytometry. The percentage of cells over a control fluorescence threshold increased from $64.08 \%$ with $100 \mathrm{nmol} / \mathrm{L}$ of $\mathrm{A} \beta$ alone (Figure 5B) to $97.76 \%$ with $100 \mathrm{nmol} / \mathrm{L}$ of $A \beta$ and $100 \mathrm{nmol} / \mathrm{L}$ of

A

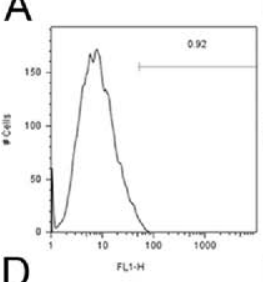

B
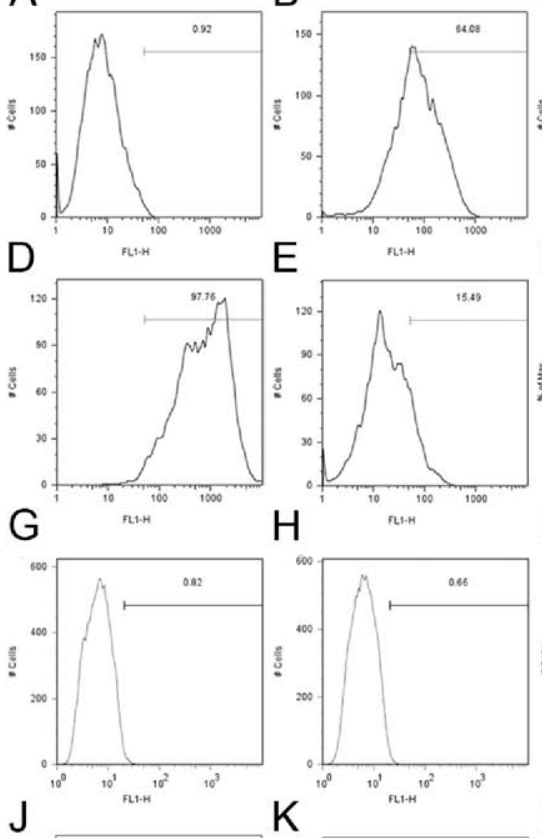

।

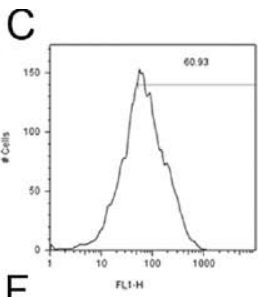

$\mathrm{F}$
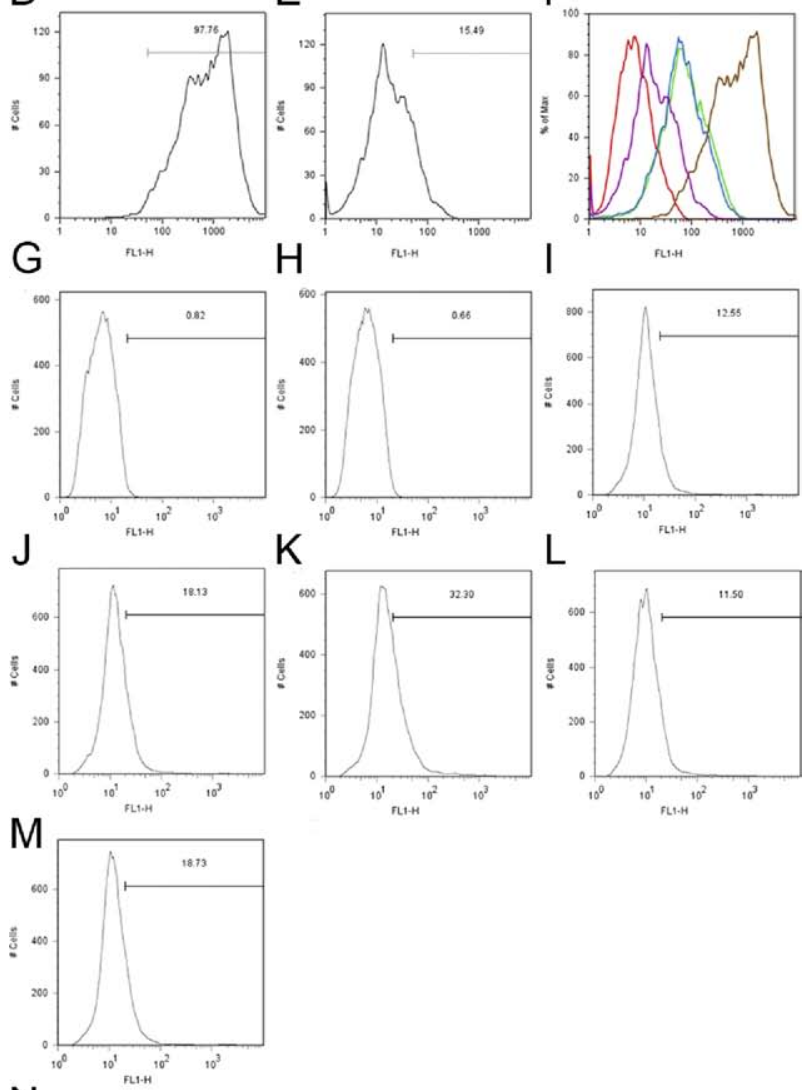

$\mathrm{N}$
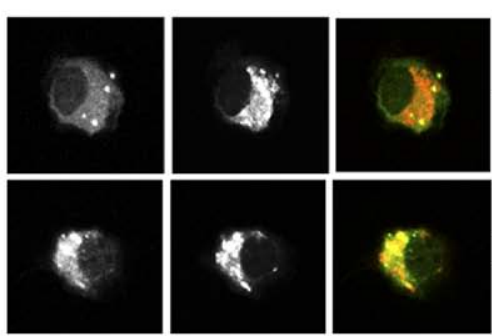

$100 \mathrm{nM} \mathrm{A} \beta$

$100 n M A \beta$

10nM PGRN
Lysotracker

$\mathrm{A} \beta$

Merge progranulin (Figure 5D), demonstrating that more cells internalized $A \beta$ in response to progranulin. Ten nanomoles per liter of progranulin did not have an effect (Figure $5 \mathrm{C}$ ). Pretreatment for 20 minutes with $5 \mu \mathrm{mol} / \mathrm{L}$ of cytocholasin $\mathrm{D}$ blocked most of the increase in fluorescence (Figure 5E), demonstrating that most, but not all, of the fluorescence associated with incubating the cells with A $\beta$ 1-42 tagged with Hilyte-488 depends on cytoskeletal rearrangement. These data suggest that $A \beta 1-42$ is being endocytosed by the microglia, that this process is increased by progranulin treatment, and that it requires cytoskeletal rearrangement by a process such as macropinocytosis. ${ }^{40}$

To confirm this observation, the experiment was repeated using primary microglia cultured from P1 C57BL/6 mice. The percentage of cells over a fluorescence threshold increased from $12.55 \%$ with $100 \mathrm{nmol} / \mathrm{L}$ of $A \beta$ alone (Figure $5 \mathrm{I}$ ) to $18.13 \%$ with $100 \mathrm{nmol} / \mathrm{L}$ of $A \beta$ and $10 \mathrm{nmol} / \mathrm{L}$ of progranulin (Figure $5 \mathrm{~J}$ ) and to $32.30 \%$ with $100 \mathrm{nmol} / \mathrm{L}$ of $A \beta$ and $100 \mathrm{nmol} / \mathrm{L}$ of progranulin. Cells were treated with other control proteins. Uptake of $A \beta$ was not affected by $100 \mathrm{nmol} / \mathrm{L}$ of insulin (Figure $5 \mathrm{~L}$ ), and $100 \mathrm{nmol} / \mathrm{L}$ of brain-derived neurotrophic factor had a limited effect (Figure $5 \mathrm{M}$ ). To confirm that $\mathrm{A} \beta$ had been internalized and to determine its subcellular localization, microglia were treated as described, and subsequently were incubated for 30 minutes with LysoTracker to label acidic compartments. A $\beta 1-42$ was observed in intracellular punctae. These punctae colocalized with acidic compartments that may be late endosomes or lysosomes (Figure $5 \mathrm{~N}$ ), demonstrating that the $\mathrm{A} \beta$ was endocytosed and delivered to the endosomal or lysosomal compartments. Consistent with the flow cytometry data, the punctae increased in progranulin-treated cells (Figure 5N). These data support the hypothesis that progranulin increases endocytosis of soluble peptides including, but not necessarily limited to, $A \beta$.

\section{Discussion}

Interest in the role of progranulin in the brain has increased dramatically since mutations in progranulin were

\footnotetext{
Figure 5. $\mathrm{C} 4 \mathrm{~B} 8$ cells and primary microglia endocytose more $\mathrm{A} \beta 1-42$ in response to progranulin treatment. A-F: C4B8 cells incubated with Hilyte 488-tagged $\mathrm{A} \beta 1-42$ and progranulin. Internalized $\mathrm{A} \beta$ was measured using flow cytometry on 488-fluorescence. A: Untreated cells. B: Cells incubated with $100 \mathrm{nmol} / \mathrm{L}$ of Hilyte 488-tagged A $\beta 1-42$. C: Cells incubated with 100 $\mathrm{nmol} / \mathrm{L}$ of Hilyte $488-$ tagged $\mathrm{A} \beta 1-42$ and $10 \mathrm{nmol} / \mathrm{L}$ of progranulin. D: Cells incubated with $100 \mathrm{nmol} / \mathrm{L}$ of Hilyte 488 -tagged $\mathrm{A} \beta 1-42$ and $100 \mathrm{nmol} / \mathrm{L}$ of proganulin. E: Cells incubated with $100 \mathrm{nmol} / \mathrm{L}$ of Hilyte 488-tagged A $\beta 1-42$ and $5 \mu \mathrm{mol} / \mathrm{L}$ of cytocholasin D. F: Mean fluorescence intensity of samples A-E: A, red; B, green; C, blue; D, brown; E, purple. G-N: Mouse primary microglia incubated with Hilyte 488-tagged $\mathrm{A} \beta 1-42$ and progranulin. G: Untreated microglia. H: Microglia incubated with $100 \mathrm{nmol} / \mathrm{L}$ of Hilyte $488-$ tagged A $\beta 1-42$. I: Microglia incubated with $100 \mathrm{nmol} / \mathrm{L}$ of progranulin. $\mathbf{J}$ : Microglia incubated with $100 \mathrm{nmol} / \mathrm{L}$ of Hilyte 488-tagged $\mathrm{A} \beta 1-42$ and 10 nmol/L of progranulin. K: Microglia incubated with $100 \mathrm{nmol} / \mathrm{L}$ of Hilyte 488-tagged A $\beta 1-42$ and $100 \mathrm{nmol} / \mathrm{L}$ of progranulin. L: Microglia incubated with $100 \mathrm{nmol} / \mathrm{L}$ of Hilyte $488-$ tagged $\mathrm{A} \beta 1-42$ and $100 \mathrm{nmol} / \mathrm{L}$ of insulin. $\mathbf{M}$ Microglia incubated with $100 \mathrm{nmol} / \mathrm{L}$ of Hilyte 488-tagged A $\beta 1-42$ and 100 $\mathrm{nmol} / \mathrm{L}$ of brain-derived neutrotrophic factor. N: Microglia incubated with $100 \mathrm{nmol} / \mathrm{L}$ of Hilyte 488 -tagged A $\beta 1-42$ and $10 \mathrm{nmol} / \mathrm{L}$ of proganulin. Acidic compartments stained with LysoTracker Red. Images obtained at $60 \times$ magnification using a Zeiss confocal microscope.
} 
Table 2. Fold-Change of Cytokines Secreted from ProgranulinTreated Primary Neurons

\begin{tabular}{|c|c|c|c|c|}
\hline \multirow[b]{2}{*}{ Cytokine } & \multirow[b]{2}{*}{ PGRN/PBS } & \multicolumn{3}{|c|}{$P$ Value } \\
\hline & & $<0.05$ & $<0.01$ & $<0.001$ \\
\hline $\mid \mathrm{P}-10$ & 8.83 & * & * & * \\
\hline IL-4 & 3.75 & * & * & * \\
\hline Ubiquitin & 2.67 & * & * & * \\
\hline FGF-BP & 21.11 & * & * & \\
\hline CCR4 & 10.07 & * & * & \\
\hline Fas ligand/TNFSF6 & 8.24 & * & * & \\
\hline IL-6 & 3.48 & * & * & \\
\hline Fractalkine & 2.59 & * & * & \\
\hline RALT/MIG-6 & 1.99 & * & * & \\
\hline Growth hormone & 1.92 & * & * & \\
\hline VEGF-C & 10.69 & * & & \\
\hline Leptin (OB) & 7.85 & * & & \\
\hline GFR- $\alpha 1$ & 3.62 & * & & \\
\hline IL-10 & 2.98 & * & & \\
\hline IL-5 & 2.04 & * & & \\
\hline MCP-1 & 1.92 & * & & \\
\hline MMP-13 & 1.73 & * & & \\
\hline TNF- $\alpha$ & 1.61 & * & & \\
\hline TRAIL & 0.30 & * & & \\
\hline VEGF & 0.57 & * & & \\
\hline
\end{tabular}

PGRN/PBS, fold-change in signal intensity in progranulin (PGRN)treated conditioned media compared with phosphate-buffered saline solution (PBS)-treated conditioned media (control). ${ }^{50}$ Asterisks indicate significance in change of expression.

Cytokines up-regulated (top section) and down-regulated (bottom section) via treatment with $10 \mathrm{nmol} / \mathrm{L}$ of progranulin for 8 hours.

linked to FTLD-U in 2006. ${ }^{1,41}$ To date, more than 50 mutations in progranulin have been identified that cause frontotemporal dementia, with a spectrum of clinical and neuropathologic phenotypes. ${ }^{42}$ Progranulin variants have also been linked to AD. 4,6,43 The number and variety of progranulin mutations linked to neurodegenerative disease underscore its prominent role in brain function. However, little is known about progranulin biology in the CNS. Relatively unbiased approaches of microarray and cytokine array analysis were selected to explore the role of progranulin in the CNS and to identify progranulinregulated mechanisms that may be involved in neurodegeneration. The pathway analysis approach was chosen to identify biological processes and functions that were regulated by progranulin and could be confirmed in animal and cellular models.

Progranulin functions as a growth factor in many tumor models, and may have a similar role in promoting growth or survival in the CNS. Pathways enriched in the progranulin-treated gene set included cell proliferation and development (Table 1). Progranulin increased the secretion of cytokines involved in cell growth and proliferation such as growth hormone, leptin, and IL-4. In addition, progranulin reduced the secretion of TRAIL, a member of the TNF superfamily that is a regulator of apoptosis. TRAIL is up-regulated in brains of patients with $A D$ and in neuronal cells treated with $A \beta$, and TRAIL neutralization blocked neuronal apoptosis in response to $A \beta{ }^{44,45}$ Reduction of TRAIL secretion may be a neuroprotective mechanism of progranulin. Secretion of GFR $\alpha 1$ was upregulated in response to progranulin treatment (Table 2). Ret pathway stimulation by soluble or immobilized
GFR $\alpha 1$ potentiates neurite outgrowth and neuronal survival and elicits dramatic localized expansion of axons and growth cones. ${ }^{46}$ Progranulin treatment also potentiated neurite outgrowth and neuron survival. ${ }^{31,47}$ Whether progranulin acts directly or indirectly to promote neuronal survival and function in vivo remains to be determined.

Neuroinflammation is increased in many neurodegenerative diseases, not least $A D$. The process has both beneficial and detrimental effects. Individual cytokines can have both pro-survival and toxic effects on neurons depending on their concentration and context. ${ }^{48}$ It was, therefore, interesting to note that although progranulin stimulated release of a number of cytokines, it did not strongly promote secretion of the classic proinflammatory cytokines such as IL-2, IFN- $\gamma$, TNF- $\alpha$, or IL- $1 \beta$, although IL-6 was up-regulated. Th2 cytokines were up-regulated (IL-4, IL-10, and IL-5) in preference to Th1 cytokines (e.g., IL-2 and IFN- $\gamma$ ). Furthermore, several of the up-regulated cytokines have been linked to neuroprotection. For example, progranulin stimulated neurons to release fractaIkine (CX3CL1), which regulates migration and structure of monocytes in the mouse olfactory bulb ${ }^{49}$ and suppresses inducible nitric oxide synthase, TNF- $\alpha$, and IL- 6 secretion from activated microglia, ${ }^{50}$ and fractalkine receptor-deficient mice are more susceptible to neurodegeneration. ${ }^{51}$ These data are complementary to the observation that bone marrow-derived macrophages from progranulin-deficient mice release less $\mathrm{IL}-10$ and more inflammatory cytokines than do wild-type mice. ${ }^{21}$

In addition to indirect modulation of inflammation via key inflammatory mediators described, the present study demonstrated that progranulin has a direct effect on the innate immune response by promoting chemotaxis and endocytosis of extracellular peptides by microglia. Dosedependent increases were observed in migration of microglia toward a higher concentration of progranulin and a dose-dependent increase in uptake of $A \beta$ by progranulin-treated microglia in vitro (Figures 3 and 5). These observations are consistent with our in vivo data (Figure 2), although it is not yet clear whether progranulin recruits distal microglia or activates local microglia in vivo. In addition, although progranulin can promote the uptake of $A \beta$ by microglia in this system, the present study did not enable determination of the extent to which this stimulus of endocytosis is specific to $A \beta$ or, as would seem more likely, whether progranulin, given appropriate conditions, can increase the endocytosis of other extracellular peptides.

Microglia are recognized as the tissue macrophages of the CNS but are heterogeneous in marker expression and function. Alternative polarized activation states of the cells have been characterized. ${ }^{52}$ The $\mathrm{M} 1$ phenotype is induced by classic activation of microglia (e.g., by lipopolysaccharide) and is characterized by production of predominantly proinflammatory cytokines such as TNF- $\alpha$, and free radicals such as nitric oxide and superoxide anions. The alternative M2 anti-inflammatory phenotype can be subdivided into an alternative activated phenotype hallmarked by arginase- 1 and induced by IL-4 or $\mathrm{IL}-13$, or a deactivated phenotype induced by IL-10 or transforming growth factor- $\beta$, and shows some increase 
in chemokine (C-C motif) receptor 2 and scavenger receptor expression, and increased phagocytic ability, but no increase in proinflammatory cytokine secretion. Progranulin does not induce neurons to secrete the proinflammatory cytokines associated with $\mathrm{M} 1$, but did promote secretion of IL-4, which induces the alternatively activated M2 phenotype. It also promoted secretion of IL-10, which induces microglia into the deactivated state of M2. Progranulin promoted phagocytic activity of microglia (evidenced by $A \beta$ uptake), which is characteristic of the M2 deactivated phenotype. These data are consistent with the hypothesis that progranulin induces differentiation of microglia into the M2 phenotype, either alternatively activated or deactivated. Further experiments profiling gene expression in progranulin-treated microglia compared with M1 and M2 microglia would confirm this hypothesis. These studies explore the role of progranulin and microglia in vitro; however, in the context of an aged degenerating brain, other factors such as extracellular lesions (e.g., A $\beta$ or prion plaques) and degenerating neurons may also contribute to the microglia phenotype.

In conclusion, the present study demonstrates for the first time that progranulin can recruit microglia, induce secretion of proliferative and Th2 or alternately activating cytokines, and increase endocytosis of an extracellular peptide. Activating the progranulin pathway may provide a novel strategy to promote microglial clearance of secreted peptides such as $A \beta$ without activation of cytotoxic cytokines.

\section{Acknowledgments}

We thank Mark Shearman for critiquing the manuscript; Sada Breegi, Minilik Angagaw, Lori Briggs, Daniel Aleksandrowicz, and Alan Wilhelm for assistance with the mice and Angie Sun and Neal Connors for generating progranulin protein.

\section{References}

1. Baker M, Mackenzie IR, Pickering-Brown SM, Gass J, Rademakers R, Lindholm C, Snowden J, Adamson J, Sadovnick AD, Rollinson S, Cannon A, Dwosh E, Neary D, Melquist S, Richardson A, Dickson D, Berger Z, Eriksen J, Robinson T, Zehr C, Dickey CA, Crook R, McGowan E, Mann D, Boeve B, Feldman H, Hutton M: Mutations in progranulin cause tau-negative frontotemporal dementia linked to chromosome 17. Nature 2006, 442:916-919

2. Rademakers R, Hutton M: The genetics of frontotemporal lobar degeneration. Curr Neurol Neurosci Rep 2007, 7:434-442

3. Neumann M, Sampathu DM, Kwong LK, Truax AC, Micsenyi MC Chou TT, Bruce J, Schuck T, Grossman M, Clark CM, McCluskey LF, Miller BL, Masliah E, Mackenzie IR, Feldman H, Feiden W, Kretzschmar HA, Trojanowski JQ, Lee VMY: Ubiquitinated TDP-43 in frontotemporal lobar degeneration and amyotrophic lateral sclerosis. Science 2006, 314:130-133

4. Brouwers N, Sleegers K, Engelborghs S, Maurer-Stroh S, Gijselinck I, van der Zee J, Pickut BA, Van den Broeck M, Mattheijssens M, Peeters K, Schymkowitz J, Rousseau F, Martin JJ, Cruts M, De Deyn PP, Van Broeckhoven C: Genetic variability in progranulin contributes to risk for clinically diagnosed Alzheimer disease. Neurology 2008, 71:656-664

5. Carecchio M, Fenoglio C, De RM, Guidi I, Comi C, Cortini F, Venturelli E, Restelli I, Cantoni C, Bresolin N, Monaco F, Scarpini E, Galimberti
D: Progranulin plasma levels as potential biomarker for the identification of GRN deletion carriers: a case with atypical onset as clinical amnesic mild cognitive impairment converted to Alzheimer's disease. J Neurol Sci 2009, 287:291-293

6. Cortini F, Fenoglio C, Guidi I, Venturelli E, Pomati S, Marcone A Scalabrini D, Villa C, Clerici F, Dalla VE, Mariani C, Cappa S, Bresolin N, Scarpini E, Galimberti D: Novel exon 1 progranulin gene variant in Alzheimer's disease. Eur J Neurol 2008, 15:1111-1117

7. Gliebus G, Rosso A, Lippa CF: Progranulin and beta-amyloid distribution: a case report of the brain from preclinical PS-1 mutation carrier. Am J Alzheimers Dis Other Demen 2009, 24:456-460

8. Pereson S, Wils H, Kleinberger G, McGowan E, Vandewoestyne M, Van Broeck B, Joris G, Cuijt I, Deforce D, Hutton M, Van Broeckhoven $C$, Kumar-Singh S: Progranulin expression correlates with dense-core amyloid plaque burden in Alzheimer disease mouse models. J Pathol 2009, 219:173-181

9. Ahmed Z, Mackenzie IR, Hutton ML, Dickson DW: Progranulin in frontotemporal lobar degeneration and neuroinflammation. J Neuroinflam 2007, 4:7

10. Baker CA, Manuelidis L: Unique inflammatory RNA profiles of microglia in Creutzfeldt-Jakob disease. Proc Natl Acad Sci USA 2003, 100:675-679

11. Johnston C, Jiang W, Chu T, Levine B: Identification of genes involved in the host response to neurovirulent alphavirus infection. J Virol 2001, 75:10431-10445

12. Malaspina A, Kaushik N, de Belleroche J: Differential expression of 14 genes in amyotrophic lateral sclerosis spinal cord detected using gridded cDNA arrays. J Neurochem 2001, 77:132-145

13. Bhandari V, Palfree RGE, Bateman A: Isolation and sequence of the granulin precursor CDNA from human bone marrow reveals tandem cysteine-rich granulin domains. Proc Natl Acad Sci USA 1992, 89 1715-1719

14. Zhu J, Nathan C, Jin W, Sim D, Ashcroft GS, Wahl SM, Lacomis L, Erdjument-Bromage $\mathrm{H}$, Tempst $\mathrm{P}$, Wright $\mathrm{CD}$, Ding A: Conversion of proepithelin to epithelins: roles of SLPI and elastase in host defense and wound repair. Cell 2002, 111:867-878

15. Kessenbrock K, Frohlich L, Sixt M, Lammermann T, Pfister H, Bateman A, Belaaouaj A, Ring J, Ollert M, Fassler R, Jenne DE: Proteinase 3 and neutrophil elastase enhance inflammation in mice by inactivating antiinflammatory progranulin. J Clin Invest 2008, 118:2438-2447

16. Daniel R, He Z, Carmichael KP, Halper J, Bateman A: Cellular localization of gene expression for progranulin. J Histochem Cytochem 2000, 48:999-1010

17. Ong CHP, He Z, Kriazhev L, Shan X, Palfree RGE, Bateman A: Regulation of progranulin expression in myeloid cells. Am J Physiol Regul Integr Comp Physiol 2006, 291:R1602-R1612

18. He Z, Bateman A: Progranulin (granulin-epithelin precursor, PC-cellderived growth factor, acrogranin) mediates tissue repair and tumorigenesis. J Mol Med 2003, 81:600-612

19. Suzuki M, Yoshida S, Nishihara M, Takahashi M: Identification of a sex steroid-inducible gene in the neonatal rat hypothalamus. Neurosc Lett 1998, 242:127-130

20. Bateman A, Belcourt D, Bennett H, Lazure C, Solomon S: Granulins, a novel class of peptide from leukocytes. Biochem Biophys Res Commun 1990, 173:1161-1168

21. Yin F, Banerjee R, Thomas B, Zhou P, Qian L, Jia T, Ma X, Ma Y ladecola C, Beal MF, Nathan C, Ding A: Exaggerated inflammation, impaired host defense, and neuropathology in progranulin-deficient mice. J Exp Med 2010, 207:117-124

22. Youn BS, Bang SI, Kloting N, Park JW, Lee N, Oh JE, Pi KB, Lee TH Ruschke K, Fasshauer M, Stumvoll M, Bluher M: Serum progranulin concentrations may be associated with macrophage infiltration into omental adipose tissue. Diabetes 2009, 58:627-636

23. He Z, Bateman A: Progranulin gene expression regulates epithelial cell growth and promotes tumor growth in vivo. Cancer Res 1999, 59:3222-3229

24. Zhou J, Gao G, Crabb JW, Serrero G: Purification of an autocrine growth factor homologous with mouse epithelin precursor from a highly tumorigenic cell line. J Biol Chem 1993, 268:10863-10869

25. Lu R, Serrero G: Inhibition of PC cell-derived growth factor (PCDGF, epithelin/granulin precursor) expression by antisense PCDGF cDNA transfection inhibits tumorigenicity of the human breast carcinoma cell line MDA-MB-468. Proc Natl Acad Sci USA 2000, 97:3993-3998 
26. Zanocco-Marani T, Bateman A, Romano G, Valentinis B, He ZH, Baserga R: Biological activities and signaling pathways of the granulin/epithelin precursor. Cancer Res 1999, 59:5331-5340

27. He Z, Ismail A, Kriazhev L, Sadvakassova G, Bateman A: Progranulin (PC-cell-derived growth factor/acrogranin) regulates invasion and cell survival. Cancer Res 2002, 62:5590-5596

28. Monami G, Gonzalez EM, Hellman M, Gomella LG, Baffa R, lozzo RV Morrione A: Proepithelin promotes migration and invasion of 5637 bladder cancer cells through the activation of ERK $1 / 2$ and the formation of a paxillin/FAK/ERK complex. Cancer Res 2006, 66:7103-7110

29. Kayasuga Y, Chiba S, Suzuki M, Kikusui T, Matsuwaki T, Yamanouchi K, Kotaki H, Horai R, Iwakura Y, Nishihara M: Alteration of behavioural phenotype in mice by targeted disruption of the progranulin gene. Behav Brain Res 2007, 185:110-118

30. Zhang YJ, Xu YF, Dickey CA, Buratti E, Baralle F, Bailey R, PickeringBrown S, Dickson D, Petrucelli L: Progranulin mediates caspasedependent cleavage of TAR DNA binding protein-43. J Neurosci 2007, 27:10530-10534

31. Van Damme $P$, Van Hoecke A, Lambrechts D, Vanacker P, Bogaert E, van Swieten J, Carmeliet P, Van Den Bosch L, Robberecht W:: Progranulin functions as a neurotrophic factor to regulate neurite outgrowth and enhance neuronal survival. J Cell Biol 2008, 181:37-41

32. Weng L, Dai H, Zhan Y, He Y, Stepaniants SB, Bassett DE: Rosetta error model for gene expression analysis. Bioinformatics 2006, 22: $1111-1121$

33. Altschul SF, Gish W, Miller W, Myers EW, Lipman DJ: Basic local alignment search tool. J Mol Biol 1990, 215:403-410

34. Aoki KF Kanehisa M: Using the KEGG database resource. Curr Protocols Bioinformatics 2005, 1.12.1-1.12.54

35. Ashburner M, Ball CA, Blake JA, Botstein D, Butler H, Cherry JM, Davis AP, Dolinski K, Dwight SS, Eppig JT, Harris MA, Hill DP, Issel-Tarver L, Kasarskis A, Lewis S, Matese JC, Richardson JE, Ringwald M, Rubin GM, Sherlock G; Gene Ontology Consortium: Gene ontology: tool for the unification of biology. Nat Genet 2000, 25:25-29

36. Mi $\mathrm{H}$, Dong $\mathrm{Q}$, Muruganujan A, Gaudet $\mathrm{P}$, Lewis $\mathrm{S}$, Thomas $\mathrm{PD}$ : PANTHER version 7: improved phylogenetic trees, orthologs and collaboration with the Gene Ontology Consortium. Nucleic Acids Res 2010, 38:D204-D210

37. Bronner IF, Bochdanovits Z, Rizzu P, Kamphorst W, Ravid R, van Swieten JC, Heutink P: Comprehensive mRNA expression profiling distinguishes tauopathies and identifies shared molecular pathways. PLoS One 2009, 4:e6826

38. Chen-Plotkin AS, Geser F, Plotkin JB, Clark CM, Kwong LK, Yuan W, Grossman M, Van Deerlin VM, Trojanowski JQ, Lee VM: Variations in the progranulin gene affect global gene expression in frontotemporal lobar degeneration. Hum Mol Genet 2008, 17:1349-1362

39. Eriksen JL, Mackenzie IR: Progranulin: normal function and role in neurodegeneration. J Neurochem 2008, 104:287-297

40. Mandrekar S, Jiang Q, Lee CY, Koenigsknecht-Talboo J, Holtzman DM, Landreth GE: Microglia mediate the clearance of soluble Abeta through fluid phase macropinocytosis. J Neurosci 2009, 29:42524262

41. Cruts M, Gijselinck I, van der Zee J, Engelborghs S, Wils H, Pirici D, Rademakers R, Vandenberghe R, Dermaut B, Martin JJ, van Duijn C, Peeters K, Sciot R, Santens P, De Pooter T, Mattheijssens M, Van den Broeck M, Cuijt I, Vennekens K, De Deyn PP, Kumar-Singh S, Van Broeckhoven C: Null mutations in progranulin cause ubiquitin-positive frontotemporal dementia linked to chromosome 17q21. Nature 2006, 442:920-924

42. van Swieten JC, Heutink P: Mutations in progranulin (GRN) within the spectrum of clinical and pathological phenotypes of frontotemporal dementia. Lancet Neurol 2008, 7:965-974

43. Brouwers N, Nuytemans K, van der Zee J, Gijselinck I, Engelborghs $S$, Theuns J, Kumar-Singh S, Pickut BA, Pals P, Dermaut B, Bogaerts V, De Pooter T, Serneels S, Van den Broeck M, Cuijt I, Mattheijssens M, Peeters K, Sciot R, Martin JJ, Cras P, Santens P, Vandenberghe R, De Deyn PP, Cruts M, Van Broeckhoven C, Sleegers K: Alzheimer and Parkinson diagnoses in progranulin null mutation carriers in an extended founder family. Arch Neurol 2007, 64:1436-1446

44. Cantarella G, Uberti D, Carsana T, Lombardo G, Bernardini R, Memo M: Neutralization of TRAIL death pathway protects human neuronal cell line from beta-amyloid toxicity. Cell Death Differ 2003, 10:134141

45. Uberti D, Cantarella G, Facchetti F, Cafici A, Grasso G, Bernardini R, Memo M: TRAIL is expressed in the brain cells of Alzheimer's disease patients. Neuroreport 2004, 15:579-581

46. Paratcha G, Ledda F, Baars L, Coulpier M, Besset V, Anders J, Scot R, Ibanez CF: Released GFRalpha1 potentiates downstream signaling, neuronal survival, and differentiation via a novel mechanism of recruitment of c-Ret to lipid rafts. Neuron 2001, 29:171-184

47. Ryan CL, Baranowski DC, Chitramuthu BP, Malik S, Li Z, Cao M, Minotti S, Durham HD, Kay DG, Shaw CA, Bennett HP, Bateman A Progranulin is expressed within motor neurons and promotes neuronal cell survival. BMC Neurosci 2009, 10:130

48. Wyss-Coray T: Inflammation in Alzheimer disease: driving force, bystander or beneficial response? Nat Med 2006, 12:1005-1015

49. Ruitenberg MJ, Vukovic J, Blomster L, Hall JM, Jung S, Filgueira L, McMenamin PG, Plant GW: CX3CL1/fractalkine regulates branching and migration of monocyte-derived cells in the mouse olfactory epithelium. J Neuroimmunol 2008, 205:80-85

50. Mizuno T, Kawanokuchi J, Numata K, Suzumura A: Production and neuroprotective functions of fractalkine in the central nervous system. Brain Res 2003, 979:65-70

51. Cardona AE, Pioro EP, Sasse ME, Kostenko V, Cardona SM, Dijkstra IM, Huang D, Kidd G, Dombrowski S, Dutta R, Lee JC, Cook DN, Jung S, Lira SA, Littman DR, Ransohoff RM: Control of microglial neurotoxicity by the fractalkine receptor. Nat Neurosci 2006, 9:917-924

52. Michelucci A, Heurtaux T, Grandbarbe L, Morga E, Heuschling P. Characterization of the microglial phenotype under specific pro-inflammatory and anti-inflammatory conditions: effects of oligomeric and fibrillar amyloid-beta. J Neuroimmunol 2009, 210:3-12 